\title{
Concord in English and Arabic: A Contrastive Study
}

\author{
Zainab Kadim Igaab ${ }^{1} \&$ Saja Mohammed Magrood Altai $^{2}$ \\ ${ }^{1}$ Dept. of English, College of Education for Humanities, Thiqar University, Nassiriya, Iraq \\ ${ }^{2}$ Ministry of Education, Directorate of Education, Nassiriya, Iraq \\ Correspondence: Zainab Kadim Igaab, Dept. of English, College of Education for Humanities, Thiqar University, \\ Nassiriya, Iraq. E-mail: zainabigaab@yahoo.com
}

Received: November 9, 2017 Accepted: November 27, 2017 Online Published: December 23, 2017

doi:10.5539/ijel.v8n2p288 URL: http://doi.org/10.5539/ijel.v8n2p288

\begin{abstract}
The present study is a descriptive, analytic and contrastive one because it describes concord in English and Arabic to arrive at the similarities and differences between the two languages. This study aims at describing, analyzing and comparing concord in English and Arabic because the phenomenon of concord has attracted a great deal of attention in the recent years. It also aims at comparing and contrasting concord between the two languages by defining it, showing its syntactic and semantic aspects and illustrating its different types and rules. This study concludes that concord as a syntactic phenomenon exists in both languages. English deals with such a topic clearly and separately in grammar while in Arabic, it is not by being explained in sentences. Arab grammarians pay attention to the role of concord in the sentence and deal with it in different grammatical topics.
\end{abstract}

Keywords: contrastive linguistics, syntax, concord

\section{Introduction}

The study aims at comparing and contrasting concord in English and Arabic by defining it, showing its syntactic and semantic aspects and illustrating its different types and rules and to what extent the two languages are similar or different from each other in terms of concord. To achieve the aims of the study, it is hypothesized that that concord is found in both languages. Grammatical concord is used more than other types. Concord explains the syntactic and semantic relations of the sentence elements in the two languages and there are similarities and differences of concord in English and Arabic and the area of differences is wider than that of similarities. The procedure of investigation in carrying out this study involves studying concord in English, then in Arabic followed by a comparison made between both languages.

\section{Definitions of Concord in English and Arabic}

Concord is the general grammatical term of the language. In a basic sense, it refers to the relationship between two grammatical units. One unit which triggers the agreement relation is known as "controller" and the other unit which is determined by the controller known as "target". These two units are determined by syntactic and semantic characteristics which are called "agreement features". This means that if the subject is the controller and the verb is the target, the agreement features are represented by the use of number and person (Corbett, 2006, pp. 4-5). It is relatively limited in the present day and it occurs between the subject and the verb in the present tense. A third person singular subject is followed by a verb with -s suffix ending. This leads to divide the types of concord into three different groups in the syntactic level. In Arabic, concord (muTaabaqa) is a grammatical phenomenon which ascertains agreement between sentence elements. Although it is a very syntactic principle, it was not given much attention by old grammarians. Concord affects sentence components to agree with each other's features:

1) The boy wrote. (alwaladu kataba)

2) The girl wrote. (albintu katabat) (Hassan, 1979, p. 205). Concord is used to clarify the meaning of the sentence since it is used in speech, poetry and holy Koran (ibn-manDur, 1955, pp. 209-210).

\section{Syntactic Aspect of Concord in English and Arabic}

\section{i. Guiding Principles}

a- Grammatical concord refers to the agreement of subject and verb, pronoun and its antecedent, subject and complement etc. It is the most fundamental type of concord in which the verb matches the subject in number. A 
singular subject agrees with a singular verb and a plural subject takes a plural verb. While Francis (1986, p. 311) justifies that grammatical concord is morphologically based which means the agreement of certain grammatical items with each other. There are two types of grammatical concord which are concord of number and person. Concord of number deals with singularity and plurality, but concord of person deals with 1st person, 2nd person and 3rd person (Leech \& Svartivk, 2002, p. 273).

b- Notional concord is the second principle of concord. It is semantically based. It refers to the agreement according to the idea of plurality in a group noun rather than a singular form of the noun. Different words or a group of nouns take either singular or plural concord like the word "family":

3) a- A new family have moved in across the street.

b- A new family has moved in across the street.

In (3) (a) above, the word "family" notionally takes the plural verb (have), but in (b) it grammatically takes the singular verb (has). The singular is used when the group is considered as a single undivided body (ibid, p. 274).

c- Proximity is the agreement of the verb with the closely preceding subject. It is positionally based in which the verb agrees with the nearest subject:

4) Either the teacher or the students are to blame for the bad results (Eckersley \& Eckersley, 1960, p. 37; Francis, 1986, p. 311). Proximity means the agreement of the noun or the pronoun with the verb which closely precedes it. The verb takes its number from whatever pronoun or noun phrase precedes it and functions as a subject:

5) No one except his own supporters agree with him.

In No. (5), the verb "agree" agrees with the number of "supporters". Although the head noun "No one" is singular, the verb agrees with the nearest noun. It is very important to note that proximity concord is reinforced by notional concord. This can be improved by the following:

6) Only his own supporters agree with him (Quirk et al., 1972, p. 360; Quirk et al., 1985, p. 757).

\section{ii. Concord of Elements}

a- Subject-verb concord: There are several rules which govern subject-verb concord. The basic rule is that the verb agrees with its subject in number and gender. The singular verb is marked with -s suffix which is collocating with the singular subject. Another rule of subject-verb concord is that the clausal subject is singular and agrees with a singular verb. If the subject is a prepositional phrase, it agrees with a singular verb. The nominal relative subject requires both singular and plural verbs. The coordinated subject takes a plural verb, but if the subject elements which are joined together refer to the same person, the verb form should be singular. When the coordinated subject is preceded by the indefinites (every, each, etc), the verb should be singular. When there is a compound subject with neither...nor and either...or, the verb agrees with the closer subject.

Naizi $(2014$, pp. 2, 12) discusses subject-verb concord according to verb tenses (simple present and past tenses) and nouns in the subject position. Simple present tense is marked by $-\mathrm{s}$ with a singular verb. It is used with 3rd person singular (he, she, it):

7) Ahmed studies English.

There are no singular-plural distinctions for the verb marked with past tense. It is unknown whether the verb (went) is plural or singular, except the verb (be) has a distinction. It shows a difference between a singular and a plural person. A singular subject takes "was" as a past form and a plural subject takes "were":

8) a- He was at home last night.

b- We were at home last night.

b- Subject and object complements concord: The subject and the object agree with their complements in number but not in person. . The subject or object and its complement relies on the general rule of concord. A singular subject or object takes a singular complement and a plural subject or object agrees with a plural complement:

9) a- My child is an angel. I consider my child an angel.

b- My children are angels. I consider my children angels (Hyams \& Wekker, 1984, p. 25; Quirk et al., 1985, p. 767).

c- Subject-object concord is another type of concord of elements. It shows number, person and gender agreement of the subject and the object. The relation between the subject and the object is determined by the general rule. A plural subject takes a plural object when the reference belongs to each individual of a group: 
10) The boys took off their coats (Quirk \& Greenbaum, 1973, p. 207; Bache \& Nielsen, 1997, p. 252).

It is not given much attention, it is only explained when the reflexive pronoun is in the object position:

11) He has hurt himself.

d- Verb-adverb concord: The agreement between the verb and adverb depends on tense. This means if the verb is in the past, the adverb must be in the past too. When the verb is in the present, the adverb should be in the present. The following sentences show disagreement between the verb and the adverb:

12) a- He is coming yesterday.

b- She came tomorrow (AlKhuli, 1999, p. 97).

e- Provisional subject refers to the use of (it) and (there) in the subject position which agree with the verb in terms of number. Provisional subject is realized by (there) which is determined by a number of the real subject:

13) a- There is a fly in my soup.

b- There are good reasons for this.

"There" is also used as a provisional existential subject to support the real subject with a predicator realized by "be":

14) There is a clear need for urgency (Klinge, 1998, p. 23; Bache, 2000, p. 99).

\section{iii- Other Types of Concord}

a- Number concord is the most essential type of concord. It is frequently marked on the verb in singular or plural forms. Number concord is indicated by adding -s to third person singular in the present tense or it is represented by different forms of the verb (be) which are (is, are, am, was and were). A coordinated subject takes a plural verb, sometimes it agrees with a singular or a plural verb when it is related to abstract nouns:

15) a- My brother and friend are here.

b- Doom and gloom was all he spoke of. (Quirk et al., 1985, p. 761; Nichols, 1992, p. 150; Penston, 2005, p. 104; Jarvie, 2007, p. 28; Dutwin, 2010, pp. 14-15).

b- Concord of person: This type of concord depends on the selection of the subject. If the subject is singular, the verb is required to be in the third-person form. Otherwise, second and first person pronouns are used (Lockwood, 2002, p. 139). Actually Greenbaum \& Nelson (2016, p. 147) show the agreement between the subject and the verb in terms of person. The verb (be) has 1st, 2nd and 3rd person concord. Whereas main verbs have only 3rd person concord:

16) a- I am your friend. (1st person singular concord)

b- He is your friend.

c- He knows you. (3rd person singular concord).

c- Concord of gender. English shows three types of gender masculine, feminine and neutral. It is defined in biological terms like - + human, - + animate and - + male. Male entities like he, him, his; female entities like she, her, hers and neutral entities are it, its. There should be a clear link between grammatical and biological features (Morava \& Tobin, 2000, pp. 185-186).

d- Concord of pronoun: It refers to the agreement of person, number and gender with the noun which it replaces or it refers to. It is also called a "Pronoun- Antecedent" (Pollard \& sag, 1994, p. 74). The agreement between the pronoun and its antecedent is a co reference rather than grammatical concord. Pronoun and its antecedent agreement is divided into three forms (person, number and gender) (Quirk et al., 1985, p. 768; Hogan, 2013, p. 189):

- Pronoun agreement with person: whenever the antecedent is personal, (he or she) is used to achieve the agreement. The pronoun (it) is used when the antecedent refers to a thing and also the second pronoun (you) is used when the antecedent is (you).

17) a- If a person wants to succeed in this game, he or she must know the rules.

b- If you want to succeed in this game, you must know the rules.

c- For this game to be successful, it needs to have specific rules.

- pronoun agreement with number

The antecedent agrees with the pronoun whether it is singular or plural: 
18) a- If people want to succeed in this game, they must know the rules.

b- If Kayla wants to succeed in this game, she must know the rules.

- pronoun agreement with gender

The pronoun agrees with its antecedent in terms of the masculine or feminine state. A singular male or female noun requires a specific gender pronoun (he, his or she, her):

19) The girl turned in her assignment (ibid, pp. 189-190).

Pronouns are divided into different groups like interrogative, relative, personal and indefinite.

Interrogative pronouns agreement requires either singular or plural verbs depending on the intended meaning. Relative pronouns agree with their antecedent in terms of gender since they can either be personal or non-personal pronouns. Personal pronouns agree with their antecedent in terms of gender and number. Indefinite pronouns show different rules because they are divided into singular indefinite which agree with singular indefinite antecedents; plural indefinite pronouns require plural antecedents and other indefinite pronouns can either be singular or plural and agree with singular or plural antecedents.

The Arabic syntactic aspect of concord includes the following:

\section{i. Grammatical Categories}

a- Case is a grammatical feature which refers to the change that happens at the end of the word because of the change of the elements (ibn-hifam, 2004, p. 19). Case plays a very important role to show the relationship between sentence elements syntactically and semantically:

20) Mohammed hit a boy. (Daraba muHamadun Gulaman) (hawand3, 2015, p. 40).

There are three cases: nominative, accusative and genitive. They are indicated by three endings: "u" for nominative, "a" for accusative and "I" for genitive.

b- number: Nouns are divided into three kinds: singular, dual and plural. The base form of the noun is singular. The dual and the plural have extensions of the form in various ways. Duality refers to the separate number category for the two of anything. It indicates the use of al-alif and al-nun in the nominative case and al-jaa? and al-nun in the accusative and genitive cases. Plurality is marked by the use of al-waaw and al-nun in the masculine nominative case and al-jaa? and al-nun in the masculine accusative and genitive cases. The feminine plural nouns are marked by the use of al-alif and al-taa?. (ibn- 9akiil, 1974, pp. 41, 54-55, 62, 84; ibn- hilam, 1979, pp. 274-276).

c- definiteness: Nouns are divided into definite and indefinite. The definite nouns are marked by the use of the definite marker (al-) which is used as a prefix and the indefinite nouns are marked by the use of "nunation" as a suffix ending. Definiteness is associated with the field of reference and context. Different nouns are not only marked by the definite marker but they can be added to other nouns to be definite (9afjfj, 1992, p. 19; Ryding, 2005, p. 156).

d- gender: Nouns are divided into masculine and feminine. The feminine nouns use different markers, but the masculine ones do not use any marker. The masculine nouns can be real, figurative, subjective and alHikami. The feminine nouns can also be real, figurative, verbal, semantic and acquired. Other nouns can either be masculine or feminine. (almubarrad, 1975, p. 115; al?anbarj, 1981, pp. 181-182; alGlayinii, 1993, p. 98).

e. person indicates the use of personal pronouns in three groups: first, second and third persons. These personal pronouns agree with their antecedents in number and gender (Hassan, 2009, pp. 108-109).

\section{ii. Subject-Predicate Concord}

This type of concord is divided into two kinds according to the type of the sentence which can either be nominal or verbal. The nominal sentence consists of the topic and comment while the verbal sentence consists of subject and verb.

a- topic-comment concord (?al mubtada? wal xabar): The topic agrees with its comment in terms of gender, number, case and definiteness. A singular masculine topic agrees with a singular masculine comment. A dual or a plural masculine topic agrees with a dual or a plural comment. The same occurs with the feminine topic to agree with its comment in singularity, duality and plurality. There are two types of the topic. The first type is a topic which is used with a comment:

21) Zaid is standing. (zajdun qa?imun) 
The topic in No. (21) is (Zaid) which agrees in number, gender and case with its comment (qa?imun). The second type is a topic which is used with a subject instead of a comment. It is only used in negative and interrogative sentences and it is considered as a described noun:

22) Are the two Zaids standing? (?aqa?imun alzajdani)

The topic of the above sentence is (qa?imu) and the comment is (al-zaidan) (ibn-9aqiil, 1980, p. 189; ibn-hifam,1990, pp. 117-118; 9umar et al., 1994, p. 341; al-a?iuubii, 2004, p. 141).

b- subject-verb concord: The verbal sentence begins either with S-V order or with V-S order. The S-V order is more general and clear. It has full agreement in terms of gender and number. When the subject is masculine, the verb must be masculine. If the subject is feminine, the verb is feminine too:

23) Mohammed is writing the lesson. (muHammadun yaktibu aldarsa)

24) Fatima is writing the lesson. (faTimatu taktibu aldarsa)

Only with feminine subjects the verb is suffixed by “taa?". This suffixation can either be obligatory or optional. If the feminine subject is not separated from the verb, the suffix is obligatory. When it is separated from its verb, the suffix is optional. If the units of the subject are coordinated by "and", the verb agrees with the closer noun. The coordinated subject is also called "multiple subject".

\section{iii. Concord of Followers}

They are called followers (?al tawabi9) because they follow other words in number, gender, case and definiteness. They are divided into four types:

a- concord of adjective: semantically, they are divided into three different types (real, causative and separated). The real adjective agrees with its preceding noun in terms of gender, number, case and definiteness. It is called real because it denotes the meaning of the described noun (al-?andulisii, 1996, p. 307). The causative adjective completes the described noun and indicates the meaning that is related to it.

It agrees with the described noun in gender, case and definiteness and it has no number agreement (wahba \& almuhandis, 1984, p. 414; Hamuda, 2014, p. 89). The separated adjective agrees with the described noun in number, gender and definiteness only. An adjective explains purposes like:

- clarification and specification: It is used to clarify and specify the described noun.

- glorification: the adjective is also used to glorify and praise the described noun.

- abasement: it denotes the disparagement of the described noun.

b- concord of conjunction/ coordination (?al 9atif): It consists of two types (9atif albajan and 9atif alnnusq). 9atif albajan agrees with its preceding noun in number, gender, case and definiteness. Its purposes are praising and affirmation (Al-zubajdii, 1990, p. 6027; 9awaD allah, 2011, p. 165; al-malhadanii, 2013, p. 193). 9atif alnnusq occurs after one of the connecters. It agrees with the preceding noun in number, gender, case and definiteness (ibn-ja9iif, 2001, pp. 72-73). The agreement of the conjunction and its preceding noun shows different forms (conjunction of nouns, conjunction of verbs and conjunction of sentences).

c- concord of affirmation (?al tawkjd): It confirms the repeated thing for the listener. It can either be verbal or denotative. The verbal affirmation means the repetition of the word whether it is a noun, pronoun, verb or particle and it agrees with the repeated word in number, case, pronunciation and meaning. The denotative affirmation refers to the repetition of the meaning. It is restricted with the use of the determiners (d3amj9, 9aama, kul, kiltaa, 9ajn, nafs, and kilaa). They are added to nouns with the same reference. (nafs and 9ajn) indicates the proportion and (kilaa, kiltaa, d3amj9, 9aama and kul) refer to the extensiveness.

d- apposition (?al badal) is another follower which consists of the following forms:

- apposition of all from all: It has the same meaning with the preceding noun.

- apposition of some from all: It refers to the second word to be a part of the first.

- apposition of inclusiveness: The apposition is included in the preceding and not a part from it.

- apposition of discrepancy: It has three forms (apposition of wrongness, apposition of forgetfulness and apposition of al?iDrab). Apposition of wrongness is used to correct the preceding noun that can be wrong. Apposition of forgetfulness indicates mentioning something which is not the intended. Apposition of al?iDrab refers to remembering something then mentioning another. 


\section{iv. Other Types of Concord}

a- concord of pronouns: pronouns agree with their antecedents in number and gender. They are divided into different types (prominent, connected and latent). There is another type of pronouns which is called "concernment pronoun" which refers to the third singular pronoun whether masculine or feminine. The use of the concernment pronoun depends on a number of conditions:

- it should be related to the noun which follows it.

- it should be interpreted in a sentence.

- it must not be followed by any one of the followers.

- it comes in the position of the topic.

- it is only singular.

The separated pronoun is used between the topic and the comment when it is definite noun. It agrees with the topic in number, gender and person.

b- concord of number: numbers can either be singular (one to ten), combined (eleven to nineteen) or coordinated (twenty one to twenty nine). The numbers (one and two) agree with the count noun in number, gender, case and definiteness while numbers from (three to ten) do not agree with gender. The combined numbers agree with the countable noun in gender. The coordinated numbers consist of two parts, the first part from (one to nine) agrees with the countable noun in gender and the second part of the coordinated numbers agrees with the first in case.

c- concord of circumstantial phrase: It is an accusative indefinite temporary description which indicates its companion and agrees with in number and gender. The circumstantial phrase explains and affirms its companion. It confirms the verb of the sentence and the nominal sentence. It also indicates interaction and arrangement.

\section{Semantic Aspect of Concord in English and Arabic}

The agreement relations in English sentence are not only based on the form (syntactic agreement), but also on the meaning (semantic agreement). This means that the meaning not the form of the subject determines the form of the verb. Semantic concord is connected with collective nouns because they have notional (semantic) agreement with the verb. They are followed by plural verbs if the subject refers to the members of the family or the group, but not the family or the group as a unit.

In Arabic, The semantic agreement between the sentence elements occurs only in one environment, that is when the plural verb agreement is expressed. The semantic role of the noun is to assert the meaning of something while the semantic role of the verb is to show the constant renewal of the meaning. Number agreement is also expressed semantically, which is the use of the plural markers semantically because the subject refers to something that is notionally plural.

\section{Negative Concord in English and Arabic}

Negative concord characterizes the vernacular language, it is also called "multiple negation or double negation". It is used in non-standard varieties of the language. It indicates the use of two or more negative words. There are two forms of negative concord: the use of negative expressions with the negative feature which is distributed over them and a negative element contains a negative expression. Sometimes, negative concord is explained by the use of non-negative words. These words are negative in meaning.

It refers to the use of the negative words which occur with negative expressions. Negative concord denotes the vernacular grammar. Several studies are used to investigate negative concord phenomenon in the language dialects. The negative expressions are "?abadan" (never), "bilmarra" (never), the negative scalar focus particle "wala" (not one) and the homophonous additive particle "wala" (nor). They are used to express negation in a sentence or they do not express negation especially when they are used in full clauses.

\section{Methodology}

The following procedures of investigation in achieving this study are adopted:

The first and second steps are giving a full description and analysis of concord in English and Arabic with showing the definition, types and rules of concord. The third is illustrating the similarities and differences between the two languages in terms of concord. Finally, the fourth step is translating every Arabic word in the Arabic sections into English and then all the examples are transliterated by using the Arabic phonetic symbols. 


\section{Conclusions}

\subsection{The Similarities}

1). Concord is found in English and Arabic as a grammatical phenomenon which has a considerable status in explaining the relationship between the elements of the sentence which are determined by syntactic and semantic characteristics.

2). Different elements of the sentence take the same features and values like case, number, gender and definiteness.

3). Concord is regarded as a sub-type of agreement.

4). Grammatical concord is considered as the most necessary type of concord and it shows more expansion than other types.

5). Pronoun-antecedent concord refers to the co reference agreement rather than the grammatical one.

\subsection{The Differences}

1). English concord is guided by a number of principles (grammatical, notional and proximity) whereas in Arabic it is achieved by grammatical categories (case, number, gender, definiteness and person).

2). In English, the sentence consists of the subject and the verb only, but Arabic sentence is divided into two types (nominal and verbal).

3). The subject in Arabic can either be postverbal or preverbal, this means that Arabic has two word orders (SVO) and (VSO) while in English, the subject is only postverbal which has one word order (SVO).

4). Subject-verb concord in English shows number and person agreement. In Arabic, the subject agrees with the verb in terms of case, number, gender and person.

5). In English, the agreement between the coordinated subject and the verb has only a plural form. While in Arabic, the coordinated subject agrees with the verb relying on proximity principle

6). Number agreement in English is marked on the verb whether singular or plural. In the singular form, it indicates the addition of -s to the third person singular whereas in Arabic, it is indicated on the verb in singularity, duality and plurality.

7). Definiteness in English is marked by the selection of the definite marker (the) and the indefinite markers (a, an). In Arabic, it is the definite marker (al-) is used as a prefix and the indefinite marker (nunation) as a suffix.

8). Gender in English denotes masculine, feminine and neutral, but in Arabic it denotes masculine and feminine only.

\section{Implication to Practice and Research}

The following recommendations are offered as possible ways to improve this study:

1). The difference in using concord in English and Arabic ought to be taken into consideration in the pedagogical process.

2). Contrastive studies ought to be taught to the undergraduate students who are learning the second language at the universities.

3). there ought to be items about contrastive studies in TOEFL tests.

4). learners must be provided with enough description of concord by EFL textbook designers.

5). There ought to be teachers who are specialized in teaching contrastive studies.

6). EFL teachers must provide the learners with a clear account of concord as a grammatical phenomenon which shows a relationship between different elements of the sentence.

A number of the suggestions for further studies are given:

1). A contrastive study of conjunctions in English and Arabic is to be made.

2). Affirmation in English and Arabic: A contrastive study is to be done.

3). A contrastive study of gender in English and Arabic can be made.

4). A contrastive and stylistic study of concord in a chosen Sura in the Holy Koran and Arabic poetry is to be made and then it is to be translated into English.

5). A similar contrastive study can be undertaken about negative concord in English and Arabic. 


\section{References}

9afjfj, A. (1992). Al-ta9rjf waltankjr fii alnaHu (1st ed.). Cairo: dar al- Oaqafa al-9arabja.

9awaD allah, B. (2011). Adhwaa fii alnaHu walSarf (Lights on Morphology and Syntax) (1st ed.). Oman: dar jaafaa al-9lmja.

9umar, A., mustafa, N., \& muHammad, H. (1994). AlnaHu al-asasj (The Basic Grammar) (4th ed.). Kuwait: ðat alsalaasil.

Al-mashhadanii, M. (2013). Al-id3maa9: diraasa fii ?iSuul alnaHu al-9arabj (Consensus: A Study in the Principles of Arabic Grammar (1st ed.). without city: Ghajdaa House.

Al-Ajuubii, A.(2004). Kitab al-kanal fii fanaj alnaHu walSarf. Beirut: almaktaba al9aSrja.

Al-Anbarj, A. (1981). Al-muthakar walmuaannath (The Masculine and feminine). Cairo: without publisher.

Al-Andalusj, M. (1996). SharH al-tashiil libn-malik (The Explanation of Ibn Malik's Tashiil) (1st ed.). Without city: dar hadar.

Al-Glajnii, M. (1993). d3aama9 al-duruus al-9arabja (A Collection of Arabic Lessons) (28th ed.). Beirut: al-maktaba al9aSrja.

Al-Khuli, M. A. (1999). Comparative Linguistics: English and Arabic (1st ed.). Sweileh: Al-Falah House.

Al-Mubarrad, A. (1975). Al-kamil (The Perfect). Cairo: maktabat dar altura $\Theta$.

Al-zubajdii, M. (1990). taad3 al-9aruus fii d3awahir al-qamuus (The Crown of the Bride in the Pearls of the Dictionary). without city: maTba9at al-Hikma.

Bache, C. (2000). Essentials of Mastering English: A Course Grammar. Berlin: Mouton de Gruyter. https://doi.org/10.1515/9783110825985

Bache, C., \& Niels, D. N. (1997). Mastering English: An Advanced Grammar for Non-Native Speakers. Berlin: Mouton de Gruyter. https://doi.org/10.1515/9783110803181

Betti, M. J. (2007). Jokes in Iraq: a Study of coherence and Cohesion. Journal of the College of Education, University of Wasit, 1(1), 399-411.

Corbett, G. G. (2006). Agreement. Cambridge: Cambridge University Press.

Dutwin, P. (2010). English Grammar Demystified: A Self Teaching Guide. US: The McGraw-Hill Companies.

Eckersley, C. E., \& Eckersley, J. M. (1960). Comprehensive English Grammar. London: Longman.

Francis, W. N. (1986). Proximity Concord in English. USA: Brown University.

Greenbaum, S., \& Nelson, G. (2016). An Introduction to English Grammar (4th ed.). London: Routledge.

Hamuda, K. M. (2014). Al-muTabaqa alnaHuja fii SaHjH albuxarj: diraasa naHuja dalalja (Syntactic Concord in $\mathrm{SaHjH}$ albuxarj : A Semantic Grammatical Study). Gaza: al-d3aami9a al-?islamja.

Hassan, T. (1979). Al-luGa Al-9arabja ma9naha wamabnaha. (Arabic Language: Its meaning and Structure) (2nd ed.). Cairo: Al-haj?a Al-maSrja Al-9ama lialkitab.

Hassan, T. (2009). Al-luGa Al-9arabja ma9naha wamabnaha (Arabic Language: Its meaning and Structure) (6th ed.). Cairo: 9aalam alkitab.

Hawand3, T. (2015). Al-muTabaqa alnaHuia fii al-luGa al-9arabja fii Daw? alisanjat al-Hadj $\Theta a$ (Syntactic Concord in Arabic in the Light of Modern Linguistics). Oman: Jordan University.

Hayms, P. J. E., \& Wekker, H. Chr. (1984). Translation Through Grammar: A graded translation course, with Explanatory Notes and a Contrastive Grammar. Berlin: Springer. https://doi.org/10.1007/978-94-017-4697-7

Hogan, G. B. (2013). Building Better Paragraphs. New York: WadsWorth Cengage Learning.

Ibn-Aqil, B. (1974). SharH ibn-9aqiil 9ala ?alfjat ibn-malik (Ibn Aqil's Explanation of Ibn Malik's Alphiyat (16th ed.). Cairo: dar alfikr.

Ibn-Aqil, B. (1980). SharH ibn-9aqiil 9ala ?alfjat ibn-malik (Ibn Aqil's Explanation of Ibn Malik's Alphiyat (20th ed.). Cairo: dar maSr.

Ibn-hisham, A. (1979). AwDaH al-masalik 9ala alfjat ibn-malik (The Most Explanatory way on Ibn Malik's Alphiyat). Beirut: dar ald3j1. 
Ibn-hisham, A. (1990). SharH quTr al-nada wabal al-Sada (1st edn). without city: maktabat Tjba.

Ibn-hisham, A. (2004). quTr al-nada wabal al-Sada. Beirut: al-maktaba al- 9aSrja.

Ibn-Ja9iish, J. (2001). SharH al-mufaSSal lil-zamxashri (1st ed.). Beirut: dar alkutub al9ilmja.

Ibn-manDur, M. (1955). Lisan al-9arab (Arabs' Language). Beirut: dar Saadr.

Jarvie, G. (2007). Bloomsbury Grammar Guide (2nd ed.). London: A\&C Black Publishers Ltd.

Klinge, A. (1998). Mastering English: A Student's Workbook and Guide. Berlin: Mouton de Gruyter. https://doi.org/10.1515/9783110804355

Leech, G., \& Svartvik, J. (2002). A Communicative Grammar of English (3rd ed.). London: Longman.

Lookwood, D. G. (2002). Syntactic Analysis and Description: A Construction Approach. London: Continuum.

Morava, E. C., \& Tobin, Y. (2000). Between Grammar and Lexicon. Amsterdam: John Benjamins Publishing Company. https://doi.org/10.1075/cilt.183

Naizi, E. (2014). Subject-Verb Agreement in English and Pashto Languages. Kabul: Kabul University.

Nichols, J. (1992). Linguistic Diversity In space and Time. London: The University of Chicago Press. https://doi.org/10.7208/chicago/9780226580593.001.0001

Penston, T. (2005). A Concise Grammar for English Language Teachers. Ireland: Tp Publications 59 Applewood Hights Greystons Co. Wicklow.

Pollard, C., \& Sag, I. A. (1994). Head-Driven Phrase Structure Grammar. Chicago: Chicago University Press.

Quirk et al. (1985). A Comprehensive Grammar of the English Language. London: Longman.

Quirk, R., \& Greenbaum, S. (1973). A University Grammar of English. London: Longman.

Quirk, R., \& Greenbaum, S., Leech, G., \& Svartvik, J. (1972). A Grammar of Contemporary English. London: Longman Group Ltd.

Ryding, K. (2005). A Reference Grammar of Modern Standard Arabic. Cambridge: Cambridge university press. https://doi.org/10.1017/CBO9780511486975

Wahba, W., \& Al-muhands, K. (1984). M9ad3am almuSTalaHat al9arabja fii aluGa wal?adab (2nd ed.). Beirut: maktabat Lebanon.

\begin{tabular}{|c|c|c|c|}
\hline \multicolumn{4}{|c|}{ A List of Arabic Symbols (Betti, 2007) } \\
\hline$/ \mathrm{f} /$ & as in & /fiil/ & "an elephant" \\
\hline$/ \Theta /$ & as in & /Өa9lb/ & "fox" \\
\hline$/ \mathrm{d} /$ & as in & /ðabha/ & "he threw it" \\
\hline /D/ & as in & /DabuT/ & "an officer" \\
\hline$/ \mathrm{s} /$ & as in & /suug/ & "market" \\
\hline$/ \mathrm{S} /$ & as in & /Sabur/ & "patience" \\
\hline$|z|$ & as in & /zraar/ & "button" \\
\hline$/ \mathrm{t} 3 /$ & as in & /t3aali/ & "bank of the river" \\
\hline$/ \mathrm{d} /$ & as in & /Jmaalak/ & "What is wrong with you" \\
\hline$/ \mathrm{x} /$ & as in & /xubuz/ & "bread" \\
\hline /G/ & as in & /Graab/ & "crow" \\
\hline$/ \mathrm{h} /$ & as in & /hnaa/ & "here" \\
\hline$/ \mathrm{H} /$ & as in & /Hariim/ & "women" \\
\hline / b / & as in & /baab/ & "door" \\
\hline$/ \mathrm{t} /$ & as in & /timman/ & "rice" \\
\hline$/ \mathrm{T} /$ & as in & /TamaTa/ & "tomatoes" \\
\hline$/ \mathrm{d} /$ & as in & /tdanna/ & "be nearby" \\
\hline
\end{tabular}




\begin{tabular}{|c|c|c|c|}
\hline /D/ & as in & /Daal/ & "staying" \\
\hline$/ \mathrm{k} /$ & as in & /ka9ak/ & “cake" \\
\hline /q/ & as in & /qadiim/ & “old” \\
\hline$/ ? /$ & as in & /?ams/ & "yesterday" \\
\hline$/ \mathrm{d} 3 /$ & as in & /d3amaal/ & "beauty" \\
\hline /g/ & as in & /ga9ad/ & "he set down" \\
\hline$/ \mathrm{m} /$ & as in & /minhuu/ & "Who is it?" \\
\hline$/ \mathrm{n} /$ & as in & /nibaH/ & "barked" \\
\hline$/ 1 /$ & as in & /limna/ & "gather us" \\
\hline$/ \mathrm{w} /$ & as in & /wajjaana/ & "with us" \\
\hline$/ \mathrm{j} /$ & as in & /jamta/ & "when" \\
\hline /9/ & as in & /9aali/ & "high" \\
\hline$/ \mathrm{r} /$ & as in & /ramul/ & "sand" \\
\hline$/ \mathrm{p} /$ & as in & /parda / & "curtain" \\
\hline$/ \mathrm{i} /$ & as in & /mi9da/ & “stomach" \\
\hline /ii/ & as in & /biina/ & "in us" \\
\hline$/ \mathrm{a} /$ & as in & /saliim/ & "healthy" \\
\hline /aa/ & as in & /salim/ & "safe" \\
\hline /oo/ & as in & /tilifoon/ & "telephone" \\
\hline$/ \mathrm{u} /$ & as in & /ummii/ & "my mother" \\
\hline /uu/ & as in & /9uud/ & "stick" \\
\hline
\end{tabular}

\section{Copyrights}

Copyright for this article is retained by the author(s), with first publication rights granted to the journal.

This is an open-access article distributed under the terms and conditions of the Creative Commons Attribution license (http://creativecommons.org/licenses/by/4.0/). 